\title{
ANGIOTENSIN CONVERTING ENZYME INHIBITORY ACTIVITY OF MELINJO (GNETUM GNEMON L.) SEED EXTRACTS AND MOLECULAR DOCKING OF ITS STILBENE CONSTITUENTS
}

\author{
ABDUL MUN'IM ${ }^{1 *}$, MUHAMMAD ASHAR MUNADHIL ${ }^{1}$, NURAINI PUSPITASARI ${ }^{1}$, AZMINAH ${ }^{2}$, ARRY YANUAR ${ }^{2}$ \\ ${ }^{1}$ Department of Pharmacognosy-Phytochemistry, Faculty of Pharmacy, Universitas Indonesia, Depok 16424, Indonesia. ${ }^{2}$ Department of \\ Biomedical Computation, Faculty of Pharmacy, Universitas Indonesia, Depok 16424, Indonesia. Email: munimabdoel@gmail.com
}

Received: 10 November 2016, Revised and Accepted: 30 November 2016

\section{ABSTRACT}

Objectives: To evaluate the angiotensin converting enzyme (ACE) inhibitory activity of melinjo (Gnetum gnemon) seed extract and to study molecular docking of stilbene contained in melinjo seeds.

Methods: Melinjo seed powders were extracted with n-hexane, dichloromethane, ethyl acetate, methanol, and water successively. The extracts were evaluated ACE inhibitory activities using ACE kit-Wist and the phenolic content using Folin-Ciocalteu method. The extract demonstrated the highest ACE inhibitory activity was subjected to liquid chromatography-mass spectrometry (LC-MS) to know its stilbene constituent. The stilbene constituents in melinjo seed were performed molecular docking using AutoDock Vina, and ligand-receptor Interactions were processed using Ligand Scout.

Results: The ethyl acetate extract demonstrated the highest ACE inhibition activity with inhibitory concentration $50 \%$ value of $9.77 \times 10^{-8} \mu \mathrm{g} / \mathrm{mL}$ and the highest total phenolic content (575.9 mg gallic acid equivalent/g). Ultra-performance LC-MS analysis of ethyl acetate extract has detected the existency of resveratrol, gnetin $\mathrm{C}, \varepsilon$-viniferin, and gnemonoside A/B. These compounds displayed similar physiochemical properties to lisinopril (ACE inhibitor), as in silico molecular docking studies demonstrated that they fit into the lisinopril receptors.

Conclusion: In vitro analysis ethyl acetate extract from melinjo seeds demonstrated the highest ACE inhibitory activity. Molecular docking analysis indicated that resveratrol dimers, gnetin $\mathrm{C}$ and gnemonoside $\mathrm{A}$ can be considered ACE inhibitor.

Keywords: Angiotensin converting enzyme inhibitor, Gnetum gnemon, Melinjo, Total phenolic, Antihypertension, Molecular docking.

(C) 2017 The Authors. Published by Innovare Academic Sciences Pvt Ltd. This is an open access article under the CC BY license (http://creativecommons. org/licenses/by/4. 0/) DOI: http://dx.doi.org/10.22159/ajpcr.2017.v10i3.16108

\section{INTRODUCTION}

Indonesia abounds with natural resources including 30,000 plant species of 40,000 species in worldwide, while the 940 of them are medicinal plants [1]. However, only a few of them that had been studied and proved benefits also the mechanism of action scientifically. Medicinal plants and vegetables provide stilbene with the interesting biological activity including apoptosis induction of colon cancer [2] and blood glucose reduction [3]. One of stilbene derivates, resveratrol which was known to provide anti-aging activity [4], antidiabetic, cardioprotective, anticancer [5], antioxidant [6], anti-inflammatory, and antithrombotic [7] so that many studies had been conducted to find the other possible potential effect which could benefit human life.

Genus Gnetum (Gnetaceae family) has been known to contains stilbene, such as resveratrol, in high concentration $[3,8,9]$. One of those plants is Gnetum gnemon L. or locally known as Melinjo, which widely cultivated in Southeast Asia. The fruit, seed, leave, and flowers of melinjo can be consumed. This plant is the staple food in some places. Melinjo is rich-in resveratrol, so very helpful in health aspect because the effect was associated with protection of cardiovascular disease, and some of cancers such as breast cancer, prostate cancer, and colorectal cancer [10-13].

The part of melinjo plant which has health benefits were the seed, leave, and root parts. The main component of melinjo seed is stilbene compound consisting gnemonoside $\mathrm{A}$, gnemonoside $\mathrm{C}$, gnemonoside D, gnetin C, gnetin L, and resveratrol [14]. Stilbene and flavonoid are polyphenolic compounds. The availability of polyphenolic compound in this melinjo thus indicated that melinjo has many biological activities which benefit on human body. According to that reason, we evaluated the angiotensin converting enzyme (ACE) inhibitory activity test and determined total phenolic content of melinjo seed extracts.

\section{METHODS}

\section{Materials}

Melinjo seeds were obtained from Melinjo Production Center, Banten Province and authenticated by Plant Conservation Center of Indonesia Science Agencies, Indonesia. The voucher specimen was deposited in Herbarium Laboratory of Pharmacognosy-Phytochemistry, Faculty of Pharmacy, Universitas Indonesia. ACE kit (Dojindo, and Japan), gallic acid, methanol, dichloromethane, n-hexane, ethyl acetate, sodium chloride, and dimethyl sulfoxide (DMSO) were purchased from Merck, Germany.

\section{Preparation of extract}

Melinjo powder ( $1 \mathrm{~kg}$ ) was refluxed with n-hexane and then filtered. The same procedure was repeated 2 times. The organic solvent was combined, and evaporated using rotary vacuum evaporator at $40^{\circ} \mathrm{C}$, and dried using oven vacuum to get hexane extract. The same procedure was applied using dichloromethane, ethyl acetate, methanol and water, successively to get dichloromethane, ethyl acetate and methanol, excluded water extract. The water solution was dried using freeze dryer to get water extract.

$\%$ Extract yield $=\frac{\text { Extract weight }}{\text { Herbweight }} \times 100$

In vitro ACE inhibition activity test

Dry extracts were dissolved in DMSO and distilled water and made in a final concentration of $100 \mu \mathrm{g} / \mathrm{ml}$. Each extract was subjected 
to ACE inhibitory assay using Dojindo ACE Kit-WST test kit (Dojindo Laboratories, Japan) as instructed in the manufacturer's protocol [15-17]. This assay used 3-hydroxybutyrate glycyl glycylglycine (3HB-GGG) as the substrate for screening of the ACE inhibitory. The absorbance value of the assay reaction was measured at $450 \mathrm{~nm}$ using microplate reader (Thermo Scientific, USA). Captopril (Kimia Farma Ltd, Indonesia) was used as a positive control in this study.

ACE inhibitory activity was measured using this following formula:

ACEinhibitionactivity $(\%)=\frac{A_{\text {blank 1 }}-A_{\text {sample }}}{A_{\text {blank 1 }}-A_{\text {blank2 }}}$

With:

$\mathrm{A}_{\text {blank 1 }}=$ Absorption values of positive controls (100\% ACE),

$A_{\text {blank } 2}=$ Absorption values of the reagents (without ACE),

$\mathrm{A}_{\text {sample }}=$ Absorption values of the extract or captopril.

Inhibitory concentration $50 \%\left(\mathrm{IC}_{50}\right.$ ) measurement could be found using various concentrations of samples linear regression equation, sample concentrations as $\mathrm{x}$-axis and the inhibition percentage as the $\mathrm{y}$-axis so that using: $\mathrm{y}=\mathrm{a}+\mathrm{bx}$ we could measure $\mathrm{IC}_{50}$ values using this following formula:

$=\frac{50-\mathrm{a}}{\mathrm{b}}$

\section{Determination of total phenolic content}

Total phenolic content was measured by Folin-Ciocalteu method referring to the Borkataky [18]. The extract (25 mg) was diluted in $25 \mathrm{ml}$ of methanol, $0.5 \mathrm{ml}$ aliquot of diluted was mixed with $2.5 \mathrm{ml}$ of $10 \%$ Folin-Ciocalteu reagent, vortexed and incubated at $25^{\circ} \mathrm{C}$. After 2 minutes, $2 \mathrm{ml}$ of $7.5 \% \mathrm{Na}_{2} \mathrm{CO}_{3}$ was added. The mixture was vortex and incubated for 60 minutes at $25^{\circ} \mathrm{C}$. The absorbance of the mixture was measured at $765 \mathrm{~nm}$ with a ultraviolet-visible spectrophotometer. Gallic acid was used as a reference, and the results were expressed as mg of gallic acid equivalents (GAE) per $g$ of the extract (mg GAE/g extract). The test was conducted in three times repetition (triplo).

\section{Mass spectrometry (MS) analysis}

Liquid chromatographic (LC) separations were conducted on a Xevo G2 Acquity Ultra-performance LC (UPLC ${ }^{\mathrm{TM}}$ ) with $\mathrm{BEH} \mathrm{C}_{18}$ column $(2.1 \mathrm{~mm}$ i.d. $\times 50 \mathrm{~mm}, 1.7 \mu \mathrm{m}$, Waters Corp., USA). The column and autosampler tray temperature were maintained at $35^{\circ} \mathrm{C}$ and $4^{\circ} \mathrm{C}$, respectively. A solution of $0.1 \%$ formic acid (A) and acetonitrile containing $0.1 \%$ formic acid (B) was used as the mobile phase at a flow rate $0.3 \mathrm{ml} / \mathrm{min}$. The gradient elution was from $95 \%$ A to $0 \%$ A within 6 minutes and then held for 1 minutes. From 7 to 7.5 minutes, the percentage of A was increased to $95 \%$ and maintained about 1.5 minutes, then reduced to the initial condition within 1 minutes and balanced for 2 minutes.

The total running time was 10 minutes and the sample injection volume was set at $5 \mu$ l. The UPLC system was connected to the MS through an electrospray ionization interface and was operated in the positive ion detection mode. Nitrogen used for desolvation was $500 \mathrm{~L} / \mathrm{h}$; cone gas was set at $16 \mathrm{~L} / \mathrm{h}$. The capillary voltage was set at $3 \mathrm{kV}$, source temperature $110{ }^{\circ} \mathrm{C}$, and desolvation temperature $300^{\circ} \mathrm{C}$. Data acquisition was processed with Masslynx 4.1 software.

\section{Molecular docking}

Structure of stilbene from melinjo seeds was downloaded from http:// www.chemspider.com/Chemical-Structure. The three-dimensional structures were saved as SMI files. Lisinopril (protein data bank [PDB] ID: 1086) was extracted from PDB. Docking studies were performed with AutoDock Vina, ligand-receptor Interactions were processed using pharmacophore feature of Ligand Scout (Inte: Ligand, Vienna, Austria). These pharmacophores can be overlaid and superimposed using a pattern-matching based alignment algorithm [19] that is solely based on pharmacophoric feature points instead of chemical structure.

\section{RESULTS AND DISCUSSION}

The result of authentification of the sample stated that the sample was G. gnemon L. Gnetaceae family. The sample was sorted to eliminate contaminant. First, we did wet sortation to separate the unwanted plants part. After that, we washed to clean the plant part from the dirt. The cleaned part then cut into small parts to ease and fasten the drying process. The next process was drying process. The chosen drying process was preventing direct sun exposure in the drying process so that hopefully the secondary metabolite contained in the study plant will not be destroyed [20]. Then, we did dry sortation to separate the herb from other unwanted things. The red fruit (ripe) was separated from the seed skin in brown which then separated again to obtain the yellow seed.

The last step of study plant was the minimizing herb size using instruments that appropriate for the herb characteristics. The minimizing process of herb was conducted using grinder, to obtain the higher extraction area so that it provided maximum process. The filtering process was conducted using sieve paper. The too small herb powder (soft powder) was not wanted because the soft powder could be released in the filtering process. While the too big size also unwanted because this will disturb the maximum extraction process. The herb then saved in a dry and protected container from the sunlight to maintain the quality [21]. We obtained $0.89 \mathrm{~kg}$ herb from $4 \mathrm{~kg}$ wet melinjo.

Melinjo dry powder (1 kg) was extracted using reflux method using gradual dissolution. The chosen method was extracted using reflux method because this method was fast and had been widely used [22]. The gradual extraction technique used to maximize the extraction process, whereas the compounds will be extracted based on the polarity properties.

In the extraction process, we obtained methanol extract provided the highest yield number with $6.37 \%$ followed by water extract with $3.90 \%$, n-hexane, ethyl acetate, and dichloromethane with the respective yields were $1.28 \%, 1.12 \%$, and $0.002 \%$ (Table 1). Methanol provided the highest yield number because methanol was a universal solvent with the polar property. After that, the extract with the second highest yield was found in water extract with 3.90\%. Water yield was not as much as methanol caused by the polarity properties of water was very high. There were not that many compounds with very high polarity properties and it was estimated that the polysaccharides were found in the water extract. These results were similar to the literature which found that the polysaccharides content such as carbohydrate in melinjo was high enough with $64.1 \%$ [23]. While the yield values of the n-hexane, ethyl acetate, dichloromethane could be estimated that melinjo seeds did not contain lots of non-polar compounds. The non-polar compound was extracted in n-hexane solvent, while the semipolar compounds were not extracted with dichloromethane and ethyl acetate solvents.

\section{ACE inhibition test and $\mathrm{IC}_{50}$ measurement test}

We conducted the in vitro ACE inhibition test of the melinjo seed extract. The study procedure was based on the ACE inhibitory test using ACE kit-WST which had been done in the previous study [24]. In this study, the ACE inhibitory activity was stated as inhibitory percentage

Table 1: The result of extraction process

\begin{tabular}{lll}
\hline Solvent & Crude extract (g) & Yield (\%) \\
\hline n-Hexane & 11.33 & 1.28 \\
Dichloromethane & 1.62 & 0.002 \\
Ethylacetate & 9.98 & 1.12 \\
Methanol & 56.35 & 6.37 \\
Water & 34.56 & 3.90 \\
\hline
\end{tabular}


values. Ethyl acetate extract demonstrated the highest ACE inhibitory activity, but still too lower that captopril as a standard (Table 2). In this study, resveratrol showed low ACE inhibitory activity, with inhibition of $41.12 \%$. The result is consistent with the previous study [25]. Su et al. 2015 studied ACE inhibitory activity of stilbene from Ampelopsis brevipedunculata var. hancei [25]

Further experiment was conducted on ethyl acetate extract and captopril standard to get their $\mathrm{IC}_{50}$. In this study, $\mathrm{IC}_{50}$ of the ethyl acetate extract is $9.77 \times 10^{-8} \mu \mathrm{g} / \mathrm{ml}$, while the $\mathrm{IC}_{50}$ for captopril was $1.13 \times$ $10^{-12} \mu \mathrm{g} / \mathrm{ml}$ (Table 3 ). This showed that this plant has potential in ACE inhibition activity. According to literatures, $\mathrm{IC}_{50}$ value for captopril was $6.87 \mathrm{nM}$ [16]; $1.0 \times 10^{-11} \mu \mathrm{g} / \mathrm{ml}$ [25]. The difference result of $\mathrm{IC}_{50}$ value from the literature and another study could be caused by many factors

Table 2: ACE inhibitory activity of Melinjo seed extracts

\begin{tabular}{lll}
\hline Sample & Concentration (ppm) & $\begin{array}{l}\text { Inhibitory } \\
\text { activity (\%)* }\end{array}$ \\
\hline n-Hexane & 100 & 79.28 \\
Dichloromethane & 100 & 89.92 \\
Ethylacetate & 100 & 92.10 \\
Methanol & 100 & 90.64 \\
Water & 100 & 89.90 \\
Resveratrol & 100 & 41.12 \\
Captopril & $1 \times 10^{-8}$ & 93.35 \\
\hline
\end{tabular}

${ }^{*} \mathrm{~N}$ : Average from triplicate data. ACE: Angiotensin converting enzyme

Table 3: $\mathrm{IC}_{50}$ of captopril and the ethyl acetate extract

\begin{tabular}{ll}
\hline Sample & IC $_{\mathbf{5 0}}(\boldsymbol{\mu g} / \mathbf{m l})$ \\
\hline Ethyl acetate extract & $9.97 \times 10^{-8}$ \\
Captopril & $1.13 \times 10^{-12}$ \\
\hline
\end{tabular}

such as the method of experiment, study conditions, enzyme source, and the association between inhibitor and enzyme sources [16]

\section{Total phenolic content}

The total phenolic content determination of the melinjo seed extract was performed using Folin-Ciocalteu method. Folin-Ciocalteau reagent was chosen because the phenolic compounds could react with Folin creating blue solution which the absorbance value could be obtained. The calibration curve used as the comparison was obtained from gallic acid which was measured in 765 wavelength. Gallic acid used as standard because it was a general phenolic compound contained in plant $[26,27]$. According to gallic acid analysis, we obtained calibration curve with the linear regression equation expressed as $y=0.1035 \mathrm{x}+$ 0.0316 with the correlation coefficient $\left(\mathrm{R}^{2}\right)=0.9958$.

GAE was a general reference to measure phenolic compound contained in materials [28]. In this study, ethyl acetate extract provided the highest total phenolic with $575.884 \mathrm{mg} \mathrm{GAE} / \mathrm{g}$ (Table 4). Polyphenol has been known to demonstrate ACE inhibitory activity in vitro and in vivo [29]. Phenolic compounds solubility depended on the solvent used. Polyphenol component had a broad spectrum with various solubility properties. The high total phenolic content in ethyl acetate solvent was expected because of the polyphenol groups such as flavonol. Ethyl acetate solvent was highly suitable for phenolic extraction. Therefore, the ethyl acetate solvent was used to extracting the phenolic compound from noni fruit (Morinda citrifolia L.) [30]. Besides that, ethyl acetate extract of corn silk (Zea mays L.) also reported having the highest total phenolic content obtained from methanol extract, water fraction, and n-hexane fraction [31].

\section{Mass analysis}

LC-MS showed that extract contains eight prominent peaks with molecular weight 149.06, 184.11, 213.15, 413.314, 414.316, 550.61, 646.44, and 756.55 au (Fig. 1). Apart from these dominant peaks, there are small peaks which may also contribute to enhance the extract

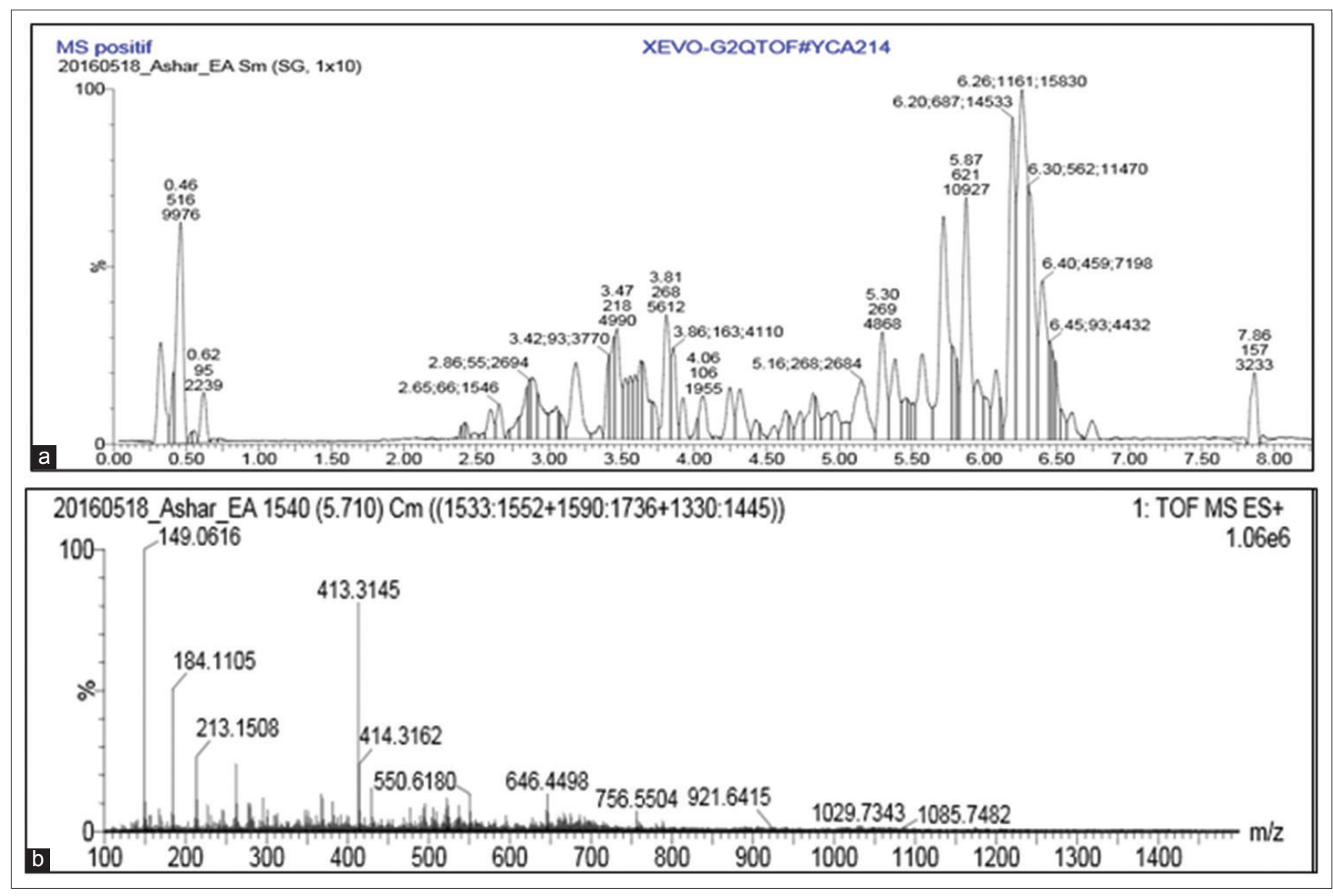

Fig. 1: (a and b) Liquid chromatography-mass spectrometry (MS)/MS chromatogram of ethyl acetate extract 
activity. Kato et al. (2002) also reported some chemical constituents from melinjo seed extract such as gnemonoside B (m/z-779.24); gnetin $\mathrm{C}(\mathrm{m} / \mathrm{z}-455.14)$; and resveratrol $(\mathrm{m} / \mathrm{z}-229.0625)$ which are responsible for their pharmacological activities. In this study, molecular weights $\mathrm{m} / \mathrm{z}-227$ au was very similar to resveratrol, $\mathrm{m} / \mathrm{z} 779.248$ was similar to gnemonoside $B$, and $\mathrm{m} / \mathrm{z}-455.19$ was similar to gnetin C [32].

\section{Molecular docking}

Docking results were calculated, and the best-docked conformation was chosen based on the number of conformations in a cluster and estimated free energy of binding. The lowest binding energy indicated better affinity of ACE inhibitor. As shown in Table 5, resveratrol gave a free energy of binding as high as affinity in $\mathrm{kcal} / \mathrm{mol},-7.90$. In contrast, the other stilbene, gnetin $\mathrm{C}$, gnemonoside $\mathrm{A}$, and gnemonoside $\mathrm{D}$ with lower free energy of binding, docked better than the original ligand in the lisinopril receptor and ACE inhibitor. Molecular docking study of tea polyphenol on ACE reported that catechin showed good affinity the active site of ACE [33].

Binding mode of compound ACE reductase (PDB 1086) by docking studies using AutodockVina, visualization by ligandScout, was shown in

Table 4: Determination of total phenolic content

\begin{tabular}{ll}
\hline Sample & Total phenolic content (mg GAE/g) \\
\hline n-Hexane & 30.611 \\
Dichloromethane & 104.102 \\
Ethylacetate & 575.884 \\
Methanol & 398.551 \\
Water & 41.224 \\
\hline
\end{tabular}

GAE: Gallic acid equivalents
Fig. 2. There are nine important amino acids which are given similarity with lisinopril, listed in Table 6. In this study, dimer of resveratrol showed better ACE inhibitory binding affinity than that monomer. This phenomena also showed stilbene from A. brevipedunculata var. hancei [25]. According to the study, tetramer of showed the highest ACE inhibitory binding affinity, followed by that trimer, dimer, and monomer [25].

Further research is needed to clarify the ACE inhibitory activity of the compounds contained in the melinjo seeds and also to evaluate ACE inhibitory activity in vivo of the ethyl acetate extract to confirm its traditional use.

\section{CONCLUSION}

Ethyl acetate extract of melinjo seeds demonstrated the strongest ACE inhibitory activity. From molecular docking, the ACE inhibitory activity from melinjo suggested that dimer of resveratrol is responsible for ACE inhibitory activity. Further, preclinical and clinical studies are needed to explore the role of this extract and their bioactive compounds from melinjo seeds in the prevention and management of hypertension.

\section{ACKNOWLEDGMENTS}

The authors wish to acknowledge the grants PITTA 2016 provided by the Directorate of Research and Community Engagement, Universitas Indonesia for this study. The funder had no role in study design, data collection and analysis, decision to publish, or preparation of the manuscript. LigandScout is licensed to ArryYanuar, Universitas Indonesia.

Table 5: Affinity/free energy of binding (kcal/mol) of lisinopril (original ligand); and stilbenein melinjo seed ethyl acetate extract

\begin{tabular}{lc}
\hline Sample & Affinity (kcal/mol) \\
\hline Lisinopril (co-crystallized) & -8.10 \\
trans-Resveratrol & -7.90 \\
Gnetol & -8.10 \\
Isorhapontigenin & -8.20 \\
trans-Piceid & -10.10 \\
Gnetin C & -10.90 \\
E-viniferin & -11.00 \\
Gnemonol M & -11.00 \\
Gnemonol K & -12.10 \\
Gnemonoside D & -12.20 \\
Gnemonoside C & -12.20 \\
Gnemonoside B & -12.50 \\
Latifolol & -12.70 \\
Gnemonoside A & -13.00 \\
\hline
\end{tabular}

Table 6: List of important amino acid in binding conformation

\begin{tabular}{ll}
\hline Ligands & Amino acids \\
\hline Lisinopril & glu162, thr166, trp279, gln281, thr282, glu376, asp377, lys511, tyr520 \\
trans-Resveratrol & asn70, glu143, val351, his383, phe512, his387, glu411, val518, arg522 \\
Gnetol & asn66, asn70, glu143, ser355 \\
Isorhapontigenin & glu143, ser355, trp357 \\
trans-Piceid & ser355, zn701, glu411, ala356, val351, tyr523 \\
Gnetin C & tyr520, glu162, ala354, val380, val379, thr282, gln281 \\
$\varepsilon$-Viniferin & asn70, glu143, val351, ala356, glu384, his387, phe512, arg522 \\
Gnemonol M & glu143, ala356, his387, glu384, arg522, asn70, trp357 \\
Gnemonol K & ala354, ser517, val518, tyr523 \\
Gnemonoside D & arg522, ala356, glu162, asn277, ala354, val380, tyr523 \\
Gnemonoside C & asn70, phe512, glu384, val518 \\
Gnemonoside B & ala356, his387, glu384, his353, val518 \\
Latifolol & ser517, tyr523, ala354, val380 \\
Gnemonoside A & thr282, glu162, glu411, ala356, asn66, tyr523, val380, ala354, gly2000, glu376 \\
\hline
\end{tabular}



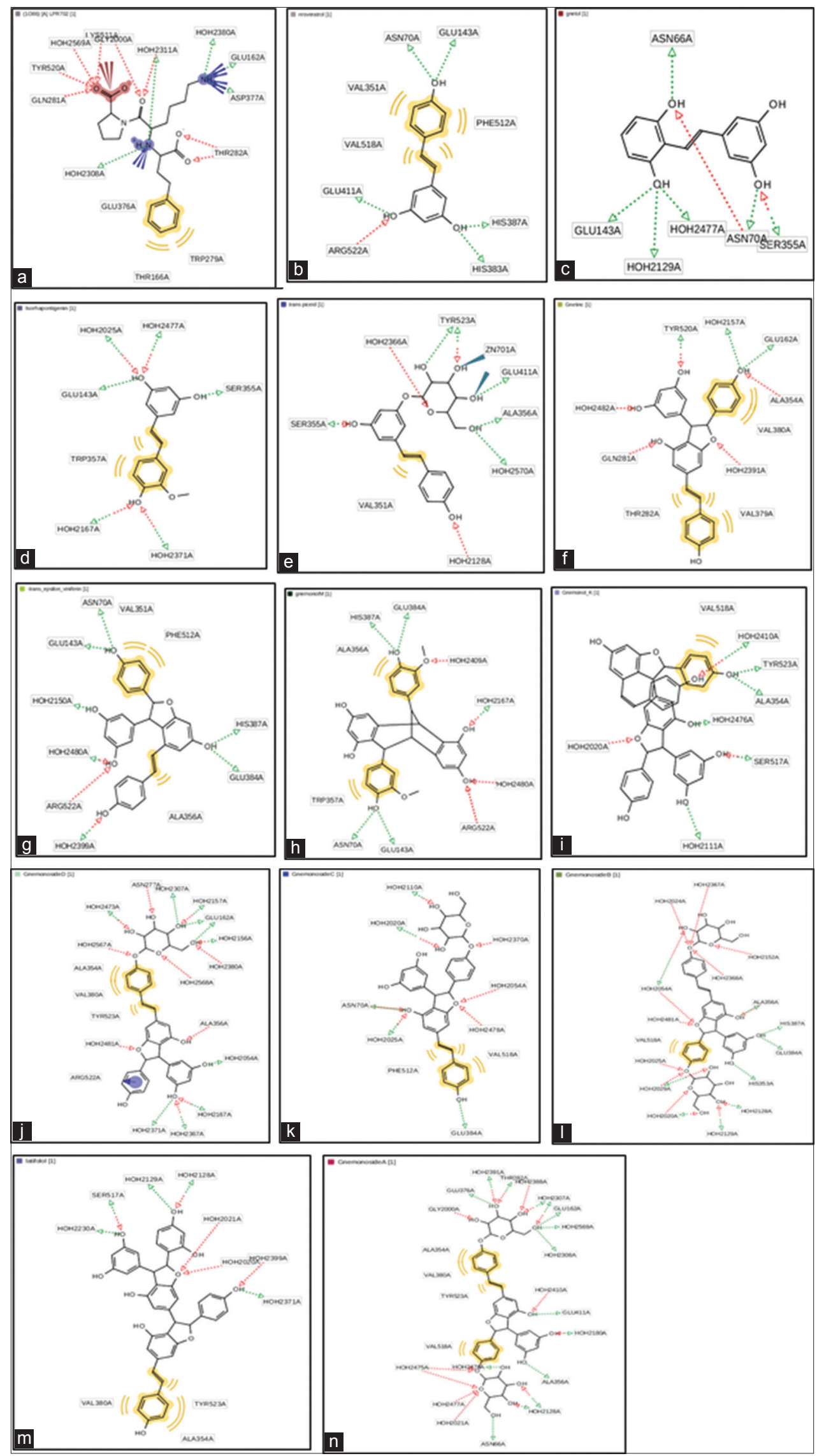

Fig. 2: Binding mode of compound angiotensin-converting enzyme reductase (PDB 1086) by docking studies using AutoDock Vina, visualition by LigandScout, (a) Lisinopril_1086, (b) trans-resveratrol_1086, (c) gnetol_1086, (d) isorhapontigenin_1086, (e) trans-piceid, (f) gnetin C_1086, (g) $\varepsilon$-Viniferin_1086, (h) gnemonol M_1086, (i) gnemonolK_1086, (j) gnemonoside D_1086, (k) gnemonosideC_1086, (l) gnemonosideB_1086, (m) latifolol_1086, (n) gnemonosideA_1086 


\section{REFERENCES}

1. Departemen Kehutanan. Lokakarya Obat Tradisional Indonesia. 2011.

2. Ito T, Akao Y, Tanaka T, Iinuma M, Nozawa Y. Vaticanol C, a novel resveratrol tetramer, inhibits cell growth through induction of apoptosis in colon cancer cell lines. Biol Pharm Bull 2002;25(1):147-8.

3. Huang KS, Wang YH, Li RL, Lin M. Five new stilbene dimers from the lianas of Gnetum hainanense. J Nat Prod 2000;63(1):86-9.

4. Baur JA, Pearson KJ, Price NL, Jamieson HA, Lerin C, Kalra A, et al. Resveratrol improves health and survival of mice on a high-calorie diet. Nature. 2006;16(7117):337-42.

5. King RE, Bomser JA, Min DB. Bioactivity of resveratrol. Compr Rev Food Sci Food Saf 2006;5(3):65-70.

6. En F. In search of better methods to evaluate natural antioxidants and oxidative stability in food lipids. Trends Food Sci Technol 1993;4(7):220-5.

7. Pace-Asciak CR, Hahn S, Diamandis EP, Soleas GD. The red wine phenolics trans-resveratrol and quercetin block human platelet aggregation and eicosanoid synthesis: Implications for protection against coronary heart disease. Clin Chim Acta 1995;235(2):207-19.

8. Huang KS, Wang YH, Li RL, Lin M. Stilbene dimers from the lianas of Gnetum hainanense. Phytochemistry 2000;54:875-81.

9. Li GH, Liu H, Shi YH, Le GW. Direct spectrophotometric measurement of angiotensin I-converting enzyme inhibitory activity for screening bioactive peptides. J Pharm Biomed Anal 2005;37(2):219-24.

10. Bradamante S, Barenghi L, Villa A. Cardiovascular protective effects of resveratrol. Cardiovasc Drug Rev 2004;22(3):169-88.

11. Le Corre L, Chalabi N, Delort L, Bignon YJ, Bernard-Gallon DJ. Resveratrol and breast cancer chemoprevention: Molecular mechanisms. Mol Nutr Food Res 2005;49:462-71.

12. Wolter F, Ulrich S, Stein J. Molecular mechanisms of the chemopreventive effects of resveratrol and its analogs in colorectal cancer: key role of polyamines? J Nutr 2004;134:3219-22.

13. Ratan HL, Steward WP, Gescher AJ, Mellon JK. Resveratrol - A prostate cancer chemopreventive agent? Urol Oncol 2002;7(6):223-7.

14. Kato E, Tokunaga Y, Sakan F. Stilbenoids isolated from the seeds of Melinjo (Gnetum gnemon L.) and their biological activity. J Agric Food Chem 2009;57:2544-9.

15. Lam le H, Shimamura T, Sakaguchi K, Noguchi K, Ishiyama M, Fujimura Y, et al. Assay of angiotensin I-converting enzyme-inhibiting activity based on the detection of 3-hydroxybutyric acid. Anal Biochem 2007;364(2):104-11.

16. Lam LH, Shimamura T, Manabe S, Ishiyama M, Ukeda H. Assay of angiotensin I-converting enzyme-inhibiting activity based on the detection of 3-hydroxybutyrate with water-soluble tetrazolium salt. Anal Sci 2008;24(8):1057-60.

17. Lam le H, Shimamura T, Ishiyama M, Ukeda H. Flow injection analysis of angiotensin I-converting enzyme inhibitory activity with enzymatic reactors. Talanta 2009;79(4):1130-4.
18. Borkataky M. Antioxidant activity, total phenolic content and total flavonoid content of Perilla ocymoides Linn. Der Pharm Lett 2015;7(5):69-72.

19. Wolber G, Dornhofer AA, Langer T. Efficient overlay of small organic molecules using 3D pharmacophores. J Comput Aided Mol Des 2006;20(12):773-88.

20. Harborne J. In: Soediro I, editor. Metode Fitokimia: Penuntun Cara Modern Menganalisis Tumbuhan. $2^{\text {nd }}$ ed. Bandung: Penerbit ITB; 1987.

21. Departemen Kesehatan Republik Indonesia. Farmakope Indonesia. Jilid IV. Jakarta: Departemen Kesehatan Republik Indonesia; 1995. p. 1995.

22. Chan HH, Sun HD, Reddy MV, Wu T. Potent $\alpha$-glucosidase inhibitors from the roots of Panax japonicus C. A. Meyer var.major. Phytochemistry 2010;71(11):1360-4.

23. Bhat R, binti Yahya N. Evaluating belinjau (Gnetum gnemon L.) seed flour quality as a base for development of novel food products and food formulations. Food Chem 2014;156:42-9.

24. Bayarsaikhan D, Yamaki K, Enkhtaivan G, Ichinkhorloo Z. Identification of angiotensin I-converting enzyme inhibitory activities from traditional Mongolian fermented milk products. Mong J Chem 2011;12(38):65-8

25. Su PS, Doerksen RJ, Chen SH, Sung WC, Juan CC, Rawendra RD, et al. Screening and profiling stilbene-type natural products with angiotensinconverting enzyme inhibitory activity from Ampelopsis brevipedunculata var. hancei (Planch.) Rehder. J Pharm Biomed Anal 2015;108:70-7.

26. Ibadallah BX, Abdullah N, Shuib AS. Identification of angiotensinconverting enzyme inhibitory proteins from mycelium of Pleurotus pulmonarius (oyster mushroom). Planta Med 2015;81(2):123-9.

27. Robinson T. In: Padmawinata K, editor. Kandungan Organik Tumbuhan Tinggi. Edisi 6. Bandung: Penerbit ITB; 1995.

28. Mongkolsilp M, Pongbupakit I, Sae-Lee N, Sitthithaworn W. Radical scavenging activity and total phenolic content of medicinal plants used in primary health care. SWUJ PharmSci 2004;9:32-5.

29. Andrade TU, Lenz D, Endringer C. Pavonia alnifolia A. St. Hil. in vivo hypotensive effect and in vitro ACE inhibitory activityY. Int J Pharm Pharm Sci 2012;4(1):124-6.

30. Rohman A, Riyanto S, Utari D. Aktivitas antioksidan, kandungan fenolik total dan kandungan flavonoid total ekstrak etil asetat buah Mengkudu Serta Fraksi-fraksinya. J MFI 2006;17(3):136-42.

31. Samin AA, Bialangi N, Salimi YK. Penentuan kandungan fenolik total dan aktivitas antioksidan dari rambut jagung (Zea mays L.) yang tumbuh di daerah Gorontalo 2011; Thesis:1-15.

32. Kato E, Tokunaga T, Iiyama M, Furusawa M, Nakaya K, Murata J, et al. Four new stilbene oligomers in the root of Gnetum gnemon. Helv Chim Acta 2002;85(8):2538-46.

33. Laskar MA, Choudhury MD. Computational study on the angiotensin converting enzyme inhibitory potential of the tea polyphenolscathechins: Relevance to cardiovascular diseases. Int J Pharm Pharm Sci $2015 ; 7(1): 345-9$. 